Assessment and Management Plan for Freshwater Fishes of India”. BCPP Species Prioritization Project. Zoo Outreach Organisation, CBSG India, Coimbatore, India, $156 \mathrm{pp}$.

Molur, S., P.O. Nameer \& S. Walker (Eds.) (1998). Report of the workshop Species Prioritization Project. Zoo Outreach Organisation, CBSG India, Coimbatore, India, 178pp.

Parthasarathy, N. \& P. Sethi (1997). Trees and Liana species diversity and population structure in a tropical dry evergreen forest in South India. Tropical Ecology 38: 19-30.

Perennou, C. (1987). Two important wetlands near Pondicherry. Blackbuck 3: 1-9.

Perennou, C. (1989). Southern wintering range of some waterbirds. Journal of the Bombay Natural History Society 86: 247-248.

Perennou, C. (1990). Peuplements d'oiseaux aquatiques en milieu anthropise: un example. Les plaines de la cote de Coromandel (Inde du Sud-Est). Diplome de Doctorat (Unpublished), 269pp.

Perennou, C. \& V. Santharam (1990). An anthropological survey of some wetlands of South-east India. Journal of the Bombay Natural History Society 87: 354-363.

Pieter (1987). Kaliveli Tank and Yedayanthittu Estuary - a little known wetland habitat in Tamil Nadu. Journal of the Bombay Natural History Society 84: 210-214.

Prater, S.H. (1993). The Book of Indian Animals. Bombay Natural History Society and Oxford Univesity Press, 324pp.

Ramanujam, M.E. (2004). Methods of analysing rodent prey in the Indian Eagle Owl Bubo bengalensis (Franklin) in and around Pondicherry, India. Zoos' Print Journal 19: 1492-1494.

Ramanujam, M.E. (2005). A preliminary report on the Ichthyofauna of Kaliveli Floodplain and Uppukalli Creek, Pondicherry, India, with some 1967-1971.

Rao, K.V.R. (1986). Valid scientific names to Day's Fish fauna of India. Records of the Zoological Survey of India, Occasional paper No 87: 1-48. Rao, T.A., S. Molur \& S. Walker (Eds.) (1998). Report on the workshop "Conservation Assessment and Mangagement Plan for Mangroves of India" (BCPP Endangered Species Project). Zoo Outreach Organisation, CBSG India, Coimbatore, India, 106pp.

Saxena, B.S. (1988). Culture of Tilapia in India - a policy issue. Proceedings of the First Indian Fisheries Forum. Asian Fisheries Society, Indian Branch,

Sharma, C.B.S.R. (1997). Ecography of small waterbodies. Madras Institute of Development Studies and Ministry of Environment and Forests, 132pp. Talwar, P.K. \& A.G. Jhingran (1991). Inland Fishes of India and Adjacent Countries. Vol. 1 \& 2. Oxford \& IBH Publishing Co.Pvt.Ltd., 1158pp.

Tikader, B.K. \& R.C. Sharma (1992). Handbook of Indian Lizards. Zoological Survey of India, 250pp.

Venkatreswaran, R. \& N. Parthasarathy (2003). Tropical dry evergreen forests on the Coromandel coast of India: Structure, Composition and Human disturbance. Ecotropica 9: 45 -58.

Whitaker, R. \& A. Captain (2004). Snakes of India - The Field Guide. Draco Books, Chengalpattu, I.N., India, 481pp. "Conservation Assessment and Management Plan for Mammals of India". BCPP notes on habitat, distribution, status and threats. Zoos' Print Journal 20: Mangalore, 39-40.

\section{SOME MACROFUNGI OF PHULWARI WILDLIFE SANCTUARY, RAJASTHAN}

\section{Satish Kumar Sharma}

Foundation For Ecological Security, 18, New Ahinsapuri, Fatehpura, Udaipur, Rajasthan 313001, India

Email:sksharma56@gmail.com

Phulwari Wildlife Sanctuary, situated at the southernmost tip of Rajasthan state near Gujarat border, experiences high rainfall, relative humidity and temperature. The presence of enormous quantity of dead and fallen wood provide congenial environment for fungi to grow. Macrofungi produce large and conspicuous fruit bodies, which have characteristic structure and appearance, which help in identification (Leelavathy \& Ganesh, 2000). Six species have been identified from Phulwari Wildlife Sanctuary (See Table below)

The macrofungi of Phulwari belong to three families. Members of the Polyporaceae family are more common than the other families. These macrofungi are responsible for the rot in fallen wood logs on the forest floor and are commonly seen during monsoon season. They are also present in Kumbhalgarh and Sitamata sanctuaries of southern Rajasthan.

Besides macrofungi, many macroscopic lichens are also present in the State. During year 2002, an ash-coloured crustaceous lichen was collected from the inner surface of the southern wall of Kumbhalgarh fort and was identified as Leraria sp. This species is commonly present at Gogunda, Jaswantgarh, Mt. Abu, Phulwari Sanctuary, Avargarh (Kamalnath), Nalmokhi, Bagdunda and Sitamata Sanctuary. It is commonly spotted on tree trunks with rough surface like Phoenix sylvestris or rough bark like Ziziphus mauritiana and Mangifera indica.

\section{REFERENCE}

Leelavathy, K.M \& P.N. Ganesh (2000). Polypores of Kerala. Daya Publishing House, Delhi.

\section{ACKnowledgements}

I thank Dr. S. Pushpangadan, Director and Dr. D.K. Upreti, Scientist E, Lichenology Lab, Plant Biodiversity and Conservation Biology Division, NBRI, Lucknow, for help in identification of macrogungi and lichen. Thanks are due to Mr. Jagdeesh Rao, Executive Director, Foundation for Ecological Security and officials of Forest Department, Rajasthan for supporting the study.

\begin{tabular}{|c|c|c|}
\hline Species & Status & Grows on \\
\hline \multicolumn{3}{|l|}{ Agaricaceae } \\
\hline $\begin{array}{l}\text { Agaricus sp. } \\
\text { Polyporaceae }\end{array}$ & Common & decaying logs of Boswellia serrata \\
\hline Polyporus picipus & Common & decaying wood logs \\
\hline Polyporus sanguineus & Less Common & decaying wood logs \\
\hline Lenzites betulina & Common & decaying wood logs \\
\hline Microporus xanthopus & Common & decaying wood logs \\
\hline \multicolumn{3}{|l|}{ Ganodermataceae } \\
\hline Ganoderma sp. & Very Common & stem of green trees \\
\hline
\end{tabular}

